\title{
Inhibitory effects of autoantibodies on the muscarinic receptors in Sjögren's syndrome
}

\author{
Jingchao $\mathrm{Li}^{1}$, Young-Min $\mathrm{Ha}^{1}$, Na-Youn $\mathrm{Kü}^{1}$, Se-Young $\mathrm{Choi}^{1}$, Sung J Lee ${ }^{1}$, Seog B Oh${ }^{1}$, \\ Joong-Soo Kim ${ }^{1}$, Jong-Ho Lee ${ }^{2}$, Eun B Lee ${ }^{3}$, Yeong W Song ${ }^{3}$ and Kyungpyo Park ${ }^{1}$
}

${ }^{1}$ Department of Physiology; ${ }^{2}$ Department of Oral Surgery, College of Dentistry and ${ }^{3}$ Department of Internal Medicine, Seoul National University and Dental Research Institute, Seoul, Korea

\begin{abstract}
Sjögren's syndrome (SS) is a systemic autoimmune disease that involves reduced salivary secretions. Recently, circulating autoantibodies from SS patients against the type 3 muscarinic cholinergic receptor (M3R) has been reported in the sera of SS patients. However, the role of these autoantibodies in the development of SS has not been elucidated. In this study, purified IgG was obtained from the sera of 11 SS patients, and its inhibitory effect on the M3R of the salivary glands was evaluated using RT-PCR, microspectrofluorimetry, immunohistochemistry, and Western blot analysis. Stimulation with carbachol (CCh) evoked a $\left[\mathrm{Ca}^{2+}\right]_{\mathrm{i}}$ transient in the fura-2 loaded HSG cells. However, pretreatment of the cells with SS lgG $(0.5 \mathrm{mg} / \mathrm{ml})$ for 12 or $24 \mathrm{~h}$ significantly reduced the magnitude of the $\mathrm{CCh}$-induced $\left[\mathrm{Ca}^{2+}\right]_{i}$ transient (CICT). We found that the magnitude of CICT was decreased by $62-45 \%$ when cells were pretreated with the SS IgG. However, the $\left[\mathrm{Ca}^{2+}\right]_{\mathrm{i}}$ response to ATP was not altered by the pretreatment of SS IgG. The effect of SS IgG on CICT was abrogated by the inclusion of excessive competitive peptides that encode the amino-acid sequence of M3R, which was not recapitulated by nonspecific peptides. The inhibitory effect of SS IgG on the aquaporin (AQP)-5 expression was also examined. After confirming the apical localization of AQP-5 along with its increase by pilocarpine $\left(10^{-5} \mathrm{M}\right)$, we examined whether SS IgG had an effect on pilocarpine-induced AQP-5 trafficking to the apical membrane (APM) using rat parotid acinar cells. After incubating the cells with SS IgG for $12 \mathrm{~h}$, the amount of pilocarpine-induced AQP-5 significantly decreased compared to the control groups. In conclusion, autoantibodies from the SS patients inhibit the function of the human M3R that is mediated by $\mathrm{Ca}^{2+}$ mobilization and AQP-5 trafficking. Our results could partly explain the underlying mechanisms of glandular dysfunction and associated features of impaired autonomic function in SS patients.
\end{abstract}

Laboratory Investigation (2004) 84, 1430-1438, advance online publication, 27 September 2004; doi:10.1038/labinvest.3700173

Keywords: sjögren's syndrome; salivary glands; cholinergic receptor; $\left[\mathrm{Ca}^{2+}\right]_{\mathrm{i}}$; aquaporin- 5

Sjögren's syndrome (SS) is a systemic autoimmune disorder that affects the salivary and lacrimal glands as well as other connective tissues. It is characterized by the lymphocytic infiltration of the salivary and lacrimal glands as well as a severe glandular dysfunction, xerostomia and xerophthalmia. ${ }^{1}$ Primary SS (pSS) patients complain of difficulties in speaking and eating, oral candidosis, rampant caries and have a high incidence of B-cell lymphomas. ${ }^{2}$

The mechanisms of the salivary secretion are well documented..$^{3-6}$ Stimulus-secretion coupling in salivary gland acinar cells is initiated by the release of acetylcholine (ACh) from the parasympathetic

Correspondence: Dr K Park, DDS, PhD, Department of Physiology, College of Dentistry, Seoul National University, Yeongeon Dong 28, Chongno Ku, Seoul 110-749, South Korea.

E-mail: kppark@snu.ac.kr

Received 6 March 2004; revised 14 July 2004; accepted 10 August 2004; published online 27 September 2004 nerves, which is mediated by an increase in the intracellular $\mathrm{Ca}^{2+}$ level, ${ }^{7-9}$ which culminates in the activation of the $\mathrm{Ca}^{2+}$-dependent $\mathrm{K}^{+}$and $\mathrm{Cl}^{-}$ channels. A disturbance in any step of these signal transduction processes will result in the decrease of fluid secretion.

Aquaporin (AQP) is a water-channel protein involved in the rapid transport of water across the cell membranes that also plays a putative role in salivary secretion. Reduced AQP-5 concentrations at the apical membrane of the acinar cells in the lacrimal and salivary glands are believed to decrease tear and saliva flow in SS patients. ${ }^{10-12}$ Trafficking of AQP-5 to the apical membrane (APM) from the cytoplasm by muscarinic receptor stimulation has been reported in the salivary gland. ${ }^{13}$

$\mathrm{Ca}^{2+}$ mobilization and AQP-5 trafficking, which are both induced by muscrinic receptor stimulation, appear to play key roles in the secretory process and determine the capacity of fluid secretion in salivary 
glands. Although it has been suggested that there are circulating autoantibodies against the M3 muscarinic cholinergic receptor (M3R) in SS patients, which is a potential diagnostic marker for SS, ${ }^{14-16}$ its effect on the muscarinic receptor is still unclear. In this study, we examined the effects of IgG that was obtained from the sera of SS patients, on the function of M3R in order to investigate the underlying pathophysiological mechanism of SS in association with a salivary dysfunction.

\section{Materials and methods}

\section{Solutions and Reagents}

A normal bath solution contained $140 \mathrm{mM} \mathrm{NaCl}$, $5 \mathrm{mM} \mathrm{KCl}, 1 \mathrm{mM} \mathrm{MgCl}_{2}, 1 \mathrm{mM} \mathrm{CaCl}_{2}, 10 \mathrm{mM}$ HEPES, 10 mM glucose; $\mathrm{pH} 7.4$ (adjusted with $\mathrm{NaOH}$ ), giving an osmolarity of 300-310 mosmol/ $\mathrm{kg} \mathrm{H}_{2} \mathrm{O}$. The BSAHEPES solution was made by adding $1 \%$ BSA, $2 \mathrm{mM}$ glutamine and $1 \times$ Minimal Eagle's medium to a normal bath solution. The Krebs-Ringer-Tris (KRT) solution contained $120 \mathrm{mM} \mathrm{NaCl}, 4.8 \mathrm{mM} \mathrm{KCl}$, $1.2 \mathrm{mM} \quad \mathrm{KH}_{2} \mathrm{PO}_{4}, 1.2 \mathrm{mM} \mathrm{MgSO}_{4}, 1 \mathrm{mM} \mathrm{CaCl}_{2}$, $16 \mathrm{mM}$ Tris-HCl; pH 7.4. The fura-2 was obtained from Molecular Probes (Eugene, OR, USA). The trypsin, trypsin inhibitor, carbachol (CCh), Adenosine $5^{\prime}$-triphosphate (ATP) and pilocarpine were obtained from Sigma (Poole, UK). The collagenase was purchased from Worthington (Lakewood, UK) and the affinity purified rabbit anti-rat AQP-5 antibody was acquired from Alpha Diagnostic (San Antonio, TX, USA).

\section{HSG Cell Culture}

The HSG cells were a generous gift from Dr Toshiko Atzumi in Meikai University in Japan. The cells were grown in a suspension in $3 \mathrm{ml}$ tissue culture plates at $37^{\circ} \mathrm{C}$ in $95 \%$ air-5\% $\quad \mathrm{CO}_{2}$, and was maintained in a minimum essential medium (MEM) supplemented with $10 \%$ fetal bovine serum (FBS). Each plate was refreshed twice a week. After the subculture, the cells were incubated with either the control or SS IgG for 12 or $24 \mathrm{~h}$ prior to carbachol (CCh) stimulation in order to measure the cytoplasmic free $\mathrm{Ca}^{2+}$ concentration $\left(\left[\mathrm{Ca}^{2+}\right]_{\mathrm{i}}\right)$.

\section{Serum IgG from SS Patients}

The purified serum IgGs were obtained from 11 SS patients. Patients were enrolled at the Rheumatology Clinic, Seoul National University Hospital between November 2000 and April 2001. All patients were diagnosed according to the revised international classification criteria for Sjögren's syndrome. ${ }^{17}$ Five patients had primary SS and six patients had secondary SS (rheumatoid arthritis in four, systemic lupus erythematosus in two). The patients were all females with ages ranging from 33 to 63 years (mean age $48.7 \pm 2.7$ years). The serum IgG obtained from six healthy controls, who did not show any sign of SS symptoms and were negative to the serologic tests. Immunoglobulin G was isolated from the serum using the Rivanol precipitation method, ${ }^{18}$ and the concentration of the purified IgG in the eluted buffer solution was $2.83 \pm 0.05 \mathrm{mg} /$ $\mathrm{ml}(n=11)$ and $2.80 \pm 0.05 \mathrm{mg} / \mathrm{ml}(n=6)$ from the SS and control group, respectively. The purified IgG diluted in MEM was added to the incubation medium containing the HSG cells with a final concentration of $0.5 \mathrm{mg} / \mathrm{ml}$ dissolved in a normal bath solution.

\section{Reverse Transcription-Polymerase Chain Reaction of Human M3R (hM3R)}

Total RNAs were subjected to reverse transcriptionpolymerase chain reaction (RT-PCR) using an oligodT reverse transcriptase primer and human M3Rspecific primers (corresponding to nucleotides 1146-1346) for the PCR. The human glyceralaldehyde-3-phosphate dehydrogenase (GAPDH) and rat $\beta$-actin were amplified to assess the cDNA yield. Primer was designed to amplify specifically the following transcripts: human GAPDH (605 bp); sense $5^{\prime}$-gga agg tga agg tcggag tc, antisense $5^{\prime}$-cag tag agg cag gga tga tg, and rat $\beta$-actin ( $482 \mathrm{bp}$ ); sense $5^{\prime}$-aca gct gag agg gaa atc gtg, antisense $5^{\prime}$-tcg tac tcc tgc ttg ctg atc. The human M3R specific primers (accession number NM_000740) were $5^{\prime}$ gtt acc ctc atc gga caa cct, $5^{\prime}$ tta ccc act gag gag ttg acg. Cycling parameters were as follows: 38 cycles of $94^{\circ} \mathrm{C}$ for $55 \mathrm{~s}, 58^{\circ} \mathrm{C}$ for $55 \mathrm{~s}$; and $72^{\circ} \mathrm{C}$ for $55 \mathrm{~s}$. An expected PCR product of approximately $201 \mathrm{bp}$ was generated.

\section{Fluorescent Dye Loading and $\left[\mathrm{Ca}^{2+}\right]_{i}$ Measurement}

Single cells of the HSG cell lines were obtained by washing out with Hanks' balanced salt solution (HBSS) and were treated with $0.01 \%$ trypsin/ $0.1 \mathrm{mM}$ EDTA after incubation. After incubation with the serum IgG for either 12 or $24 \mathrm{~h}$, the HSG cells were washed twice with a BSA-HEPES solution and then loaded with $2 \mu \mathrm{M}$ Fura-2 acetoxymethyl ester (fura-2) in $2 \mathrm{ml}$ of the same solution for $30 \mathrm{~min}$ at room temperature $\left(25^{\circ} \mathrm{C}\right)$. After loading, the cells were centrifuged, washed, resuspended in a normal bath solution, and stored on ice until needed. For the microspectrofluorimetric measurements of $\left[\mathrm{Ca}^{2+}\right]_{\mathrm{i}}$, the cells were allowed to settle at the bottom of a recording chamber (volume $400 \mu \mathrm{l}$ ) and were viewed using a Zeiss inverted microscope (Axiovert 10, Zeiss, Germany) with an $\times 40$ oil immersion objective lens. After the cells had adhered to the coverslip forming the base of the chamber, they were superfused with the normal bath solution at a flow rate of $1.3-1.7 \mathrm{ml} / \mathrm{min}$. For excitation of fura-2, a collimated beam of light from a $200 \mathrm{~W} \mathrm{Hg}$ arc lamp was fed to a dual spectro- 
photometer system (PTI, USA), which had an alternating wavelength between 340 and $380 \mathrm{~nm}$ using a spinning chopper $(60 \mathrm{~Hz})$. The emitted fluorescence was measured at $510 \mathrm{~nm}$ using a photomultiplier tube. Felix software (Version 1.1) from PTI was used for the recording and analysis. The results are presented as the measured $340 \mathrm{~nm} /$ $380 \mathrm{~nm}$ ratio $\left(\mathrm{Ca}^{2+}\right.$ fluorescence ratio, F340/F380). All the results are presented as a mean \pm s.e.m. Statistical analysis was performed using Student's unpaired $t$-test.

\section{M3R Peptides Design to Block the SS IgG}

The hM3R is a transmembrane receptor with seven transmembrane domains. Protein sequences exposed to the outside of the cells are predicted according to the hydropathy plot based on the protein sequence, and six peptides were designed to cover all the extracellular portion of the hM3R. ${ }^{19,20}$ Excess amount of all six M3R peptides $(10 \mu \mathrm{M}$ each) were added into the incubation medium containing SS IgG to block the effect of anti-M3R antibody of SS IgG. The sequences of six peptides used in this experiment were as follows:

\section{MTLHNNSTTSPLFPNISSWIHSPSDA, HSPSDAGLPPGTVTHFGSYNVSRAAGN, RAAGNFSSPDGTTDDPLGGHTVWQV, MNRWALGNLACDLW, LFWQYF VGKRTVPPGE CFIQFLSEPT, NTFCDSC IPKTFWN.}

Nonspecific peptides used for control experiment, were made by degradation of bovine serum albumin (BSA) (sigma A-2153) by $50 \mu \mathrm{g} / \mathrm{ml}$ trypsin (Sigma) treatment for $1 \mathrm{~h}$ at $37^{\circ} \mathrm{C}$. The residual trypsin was inactivated by heating the mixture at $60^{\circ} \mathrm{C}$.

\section{Immunohistochemistry for Parotid Acinar Cells}

After a transcardiac perfusion in rats with $3 \%$ paraformaldehyde, the parotid glands were isolated and paraffin blocked. After microdissecting the block with a $3 \mu \mathrm{m}$ thickness, the sections were deparaffinized and microwaved for $10 \mathrm{~min}$. Subsequently, the sections were soaked in PBS containing $50 \mathrm{mM} \mathrm{NH}_{4} \mathrm{Cl}$ for $30 \mathrm{~min}$ and treated with a blocking buffer (1\% BSA, $0.2 \%$ gelatin, $0.05 \%$ saponin in PBS) for $0.5-1 \mathrm{~h}$. The sections were then incubated with the affinity purified rabbit anti-rat AQP-5 antibody (diluted 1:800) that was raised against the 17-amino-acid sequence of the $\mathrm{COOH}$ terminus of the rat AQP-5 in PBS containing 0.3\% Triton X-100, $0.1 \%$ BSA at $4{ }^{\circ} \mathrm{C}$ overnight. After washing out with PBS containing $0.1 \%$ BSA, $0.2 \%$ gelatin and $0.05 \%$ saponin, the sections were incubated with the secondary antibody (P448, DAKO, diluted 1:200) using the same incubation medium for $1 \mathrm{~h}$. After rinsing, the sections were visualized with diamino- benzidine and stained with hematoxylin for $<2$ min. The sections were then washed using tap water for 15-20 min and sequentially dehydrated in a graded series of ethanol (70, 96 and 99\%). The samples were mounted after being cleared in xylene.

\section{Western Blot Analysis}

The tissues obtained from the rat parotid gland were sliced with blades in a KRT solution. The sections had an average thickness of $100 \mu \mathrm{m}$. After incubating the cells with the KRT solution for $15 \mathrm{~min}$ at $37^{\circ} \mathrm{C}$, purified IgG from either SS patients or normal healthy controls was added to the incubation medium to a final concentration of $0.5 \mathrm{mg} / \mathrm{ml}$. The experimental groups were divided into three according to the incubation periods with $\operatorname{IgG}(1,6$ and $12 \mathrm{~h}$ ). After incubation, $10 \mu \mathrm{M}$ pilocarpine was applied to each group for $3 \mathrm{~min}$. The membrane fraction of the apical membrane (APM) was obtained according to the method reported by Ishikawa et $a{ }^{13} \gamma$-GT and KpNPPase were used as a marker of the APM and basolateral membranes (BLM), respectively. After electrophoresis of the APM in a sodium dodecyl sulfate-polyacrylamide gel (SDS-PAGE, $12 \%$ gel), it was transferred to a nitrocellulose membrane (Hybond-P:PVDF Membrane, Amersham Pharmacia Biotech, UK). The target protein was then incubated with the primary antibody (Anti-AQP-5 antibody, diluted 1:2000) for $2 \mathrm{~h}$ at room temperature, which was detected with the horseradish peroxidase-conjugated secondary antibody (diluted 1:2000) and the ECC reagent (Amersham Pharmacia Biotech, UK) after $1 \mathrm{~h}$.

\section{Results}

Effect of SS IgG on the CCh-Induced $\left[\mathrm{Ca}^{2+}\right]_{\mathrm{i}}$ Transient

Carbachol (CCh) is a well-known muscarinic cholinergic agonist that increases the $\left[\mathrm{Ca}^{2+}\right]_{\mathrm{i}}$ in salivary acinar cells ${ }^{9}$ including the HSG cell lines. ${ }^{21}$ We first examined whether M3R, the receptor at which CCh acts, is expressed in HSG and rat parotid acinar cells. Figure 1a shows RT-PCR products that detect mRNA of M3R. M3R was detected in both tissues. Figure $1 \mathrm{~b}$ shows a typical $\left[\mathrm{Ca}^{2+}\right]_{\mathrm{i}}$ response to $10^{-4} \mathrm{M}$ CCh in HSG cells. The $\left[\mathrm{Ca}^{2+}\right]_{i}$ response was consistent but desensitization was observed by repeated CCh stimulation. Figure 1c shows a concentration-response curve of CCh on HSG. $\left[\mathrm{Ca}^{2+}\right]_{\mathrm{i}}$ was increased in proportion to the concentration of CCh in the range from $10^{-7}$ to $10^{-3} \mathrm{M}$, supramaximal concentration. The $\mathrm{EC}_{50}$ of CCh was estimated as $52 \pm 18 \mu \mathrm{M}$. Then we examined the effects of SS IgG on CCh-induced $\left[\mathrm{Ca}^{2+}\right]_{\mathrm{i}}$ transient (CICT). Figure 2 shows CICTs after incubating the HSG cells with the IgGs. The cells had been incubated for two different incubation periods, $12 \mathrm{~h}$ (a) and $24 \mathrm{~h}$ (b). In the left panels of Figure 2a 
a
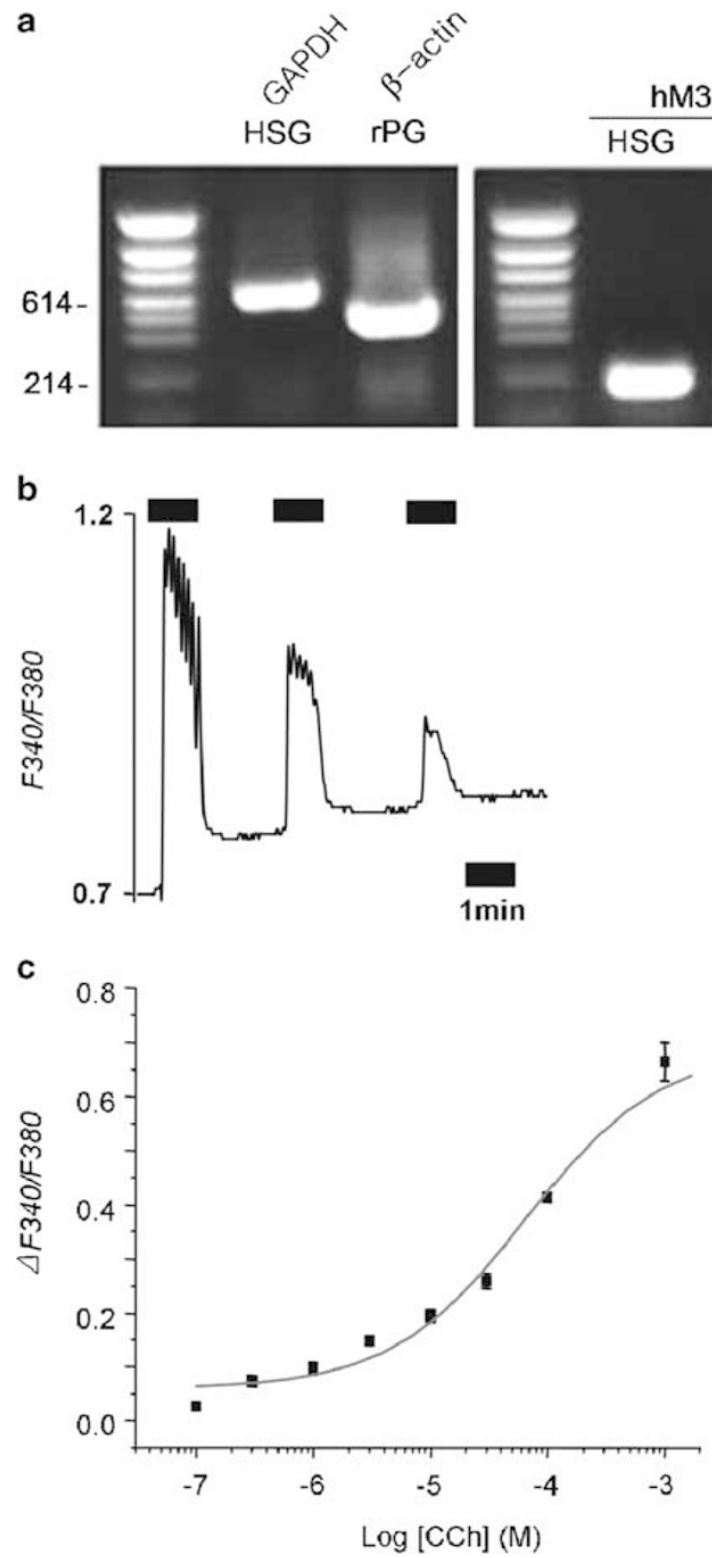

Figure 1 (a) RT-PCR products to detect messenger RNA (mRNA) of M3R in HSG and rat parotid acinar cells. An expected PCR product for M3R was detected around $200 \mathrm{bp}$. (b) A typical $\left[\mathrm{Ca}^{2+}\right]_{\mathrm{i}}$ response to repetitive CCh $\left(10^{-4} \mathrm{M}\right)$ stimulation in HSG cells. The response was consistent with a desensitization. The dark bars indicate the period of CCh stimulation and the vertical axis represents the $\mathrm{Ca}^{2+}$ fluorescence ratio $\left(\mathrm{F}_{340} / \mathrm{F}_{380}\right)$. (c) A concentration-response curve of CCh in HSG $(n=6-60$ at each concentration). $\mathrm{EC}_{50}=52 \pm 18 \mu \mathrm{M}$. $\left[\mathrm{Ca}^{2+}\right]_{\mathrm{i}}$ increased in proportion to the concentration of CCh. The vertical axis indicates the magnitude of $\left[\mathrm{Ca}^{2+}\right]_{\mathrm{i}}$ increase $\left(\Delta\left[\mathrm{Ca}^{2+}\right]_{\mathrm{i}}\right)$.

and $b$, purified IgGs from the normal healthy persons were added to the incubation medium for the control experiment, whereas in the right panels, SS IgGs were used. Throughout the experiments, the HSG cells in the control groups (left panels of Figure 2a and b) responded consistently to CCh $\left(10^{-4} \mathrm{M}\right)$ by increasing the $\left[\mathrm{Ca}^{2+}\right]_{\mathrm{i}}$. Although reproducible CChinduced $\left[\mathrm{Ca}^{2+}\right]_{\mathrm{i}}$ transient (CICTs) were also observed a
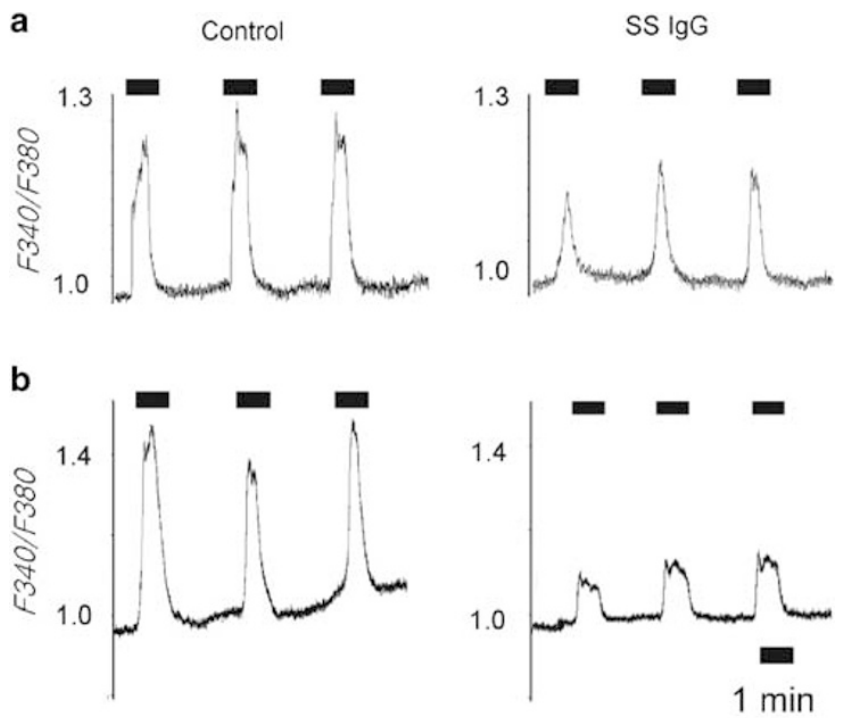

C

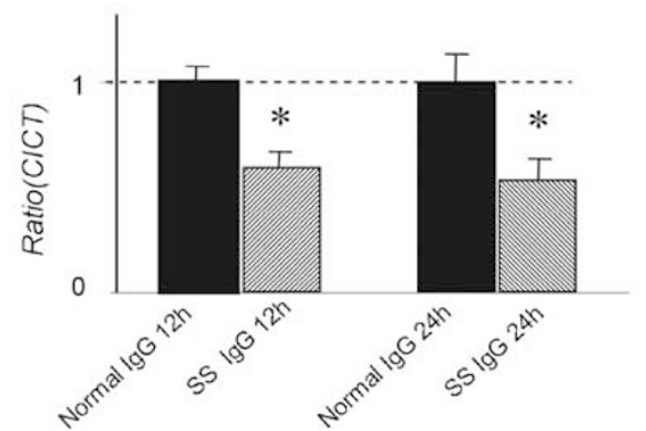

Figure 2 Effects of SS IgG on the CCh-induced $\left[\mathrm{Ca}^{2+}\right]_{\mathrm{i}}$ transient (CICT). (a) A typical CICTs after incubation of HSG with the normal (left panel) or SS IgG (right panel) for $12 \mathrm{~h}$. CICTs significantly decreased after SS IgG incubation. (b) A typical CICT after incubation with SS IgGs for $24 \mathrm{~h}$ incubation. A decrease in the CICT (right panel) was more prominent than $12 \mathrm{~h}$ incubation with the SS IgG. (c) A summarized result of these experiments. Upon incubation with the SS IgG for $12 \mathrm{~h}$ or $24 \mathrm{~h}$, CICT significantly decreased to $62 \pm 6 \%(n=12, P<0.05)$ and $45+6 \% \quad(n=15, P<0.05)$, respectively. The magnitude of CICT was expressed as the ratio of CICT of each sample to that of control sample in which cells were incubated with normal IgG for 12 or $24 \mathrm{~h}$

in the SS IgG incubation groups (right panels of Figure 2a and b), the magnitudes of the CICTs $\left(\Delta\left[\mathrm{Ca}^{2+}\right]_{\mathrm{i}}\right)$ were substantially lower than those of control groups. A decrease in the CICT was more prominent after $24 \mathrm{~h}$ incubation with the SS IgG (right panel in Figure 2b). We found that the muscarinic receptors of the HSG cells still work but CICTs significantly decreased to $62 \pm 6 \%$ (mean \pm s.e.m., $P<0.05)$ and $45 \pm 6 \% \quad(P<0.05)$ in $12 \mathrm{~h}$ and $24 \mathrm{~h}$ SS IgG incubation group, respectively (Figure 2c).

We also examined the acute effect of SS IgG alone and found that the application of SS IgG did not decrease the $\left[\mathrm{Ca}^{2+}\right]_{\mathrm{i}}$. Figure $3 \mathrm{a}$ shows a typical $\left[\mathrm{Ca}^{2+}\right]_{\mathrm{i}}$ response to the SS IgG application. SS IgG applied in between CCh stimulation (indicated by a white bar) did not evoke any $\left[\mathrm{Ca}^{2+}\right]_{\mathrm{i}}$ transient even 


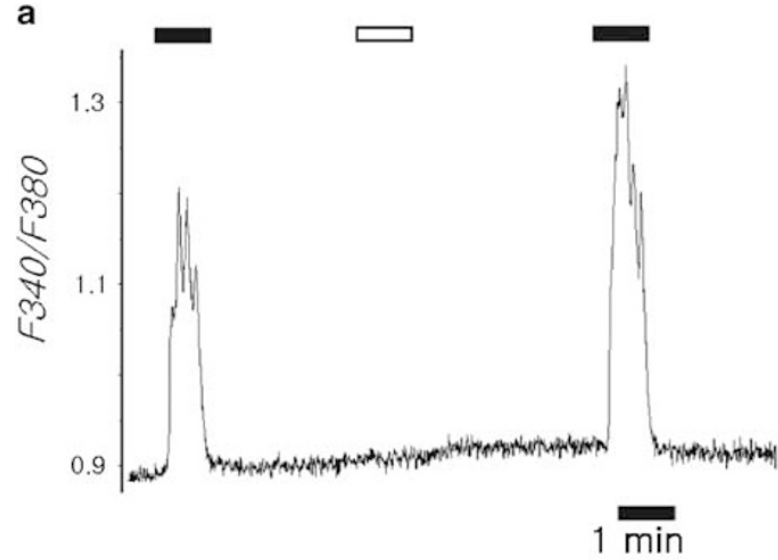

b
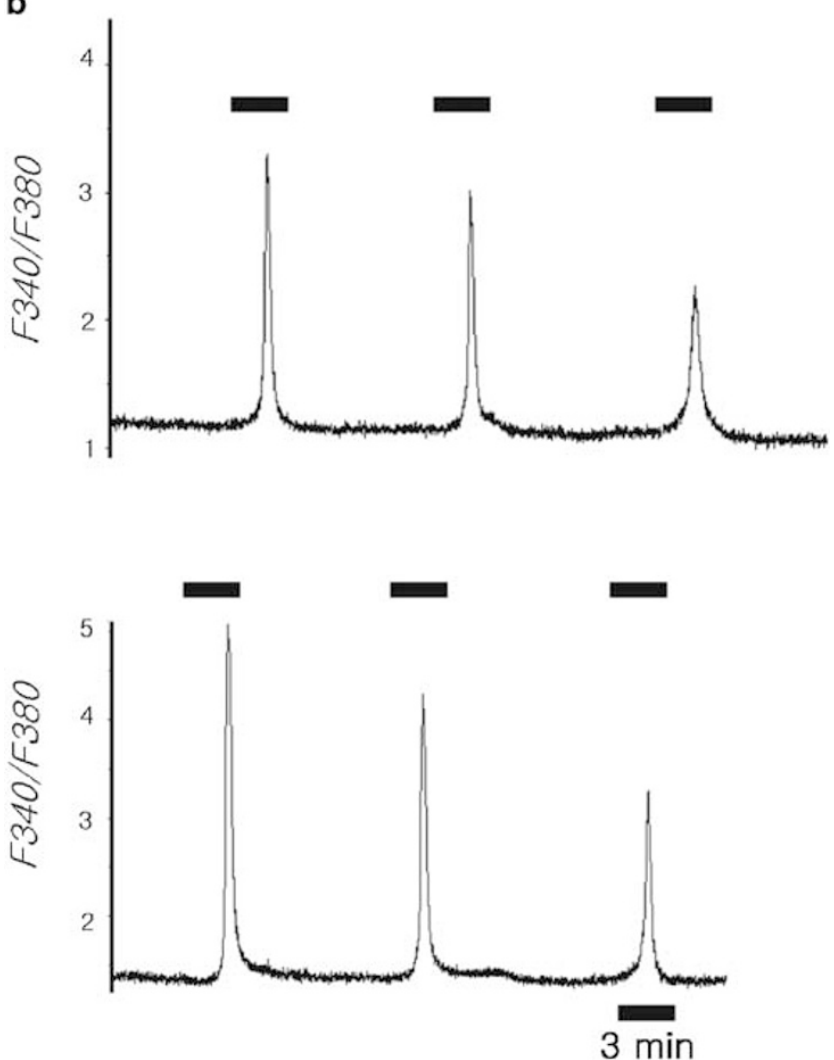

Figure 3 (a) A representative $\left[\mathrm{Ca}^{2+}\right]_{\mathrm{i}}$ response showing the acute effect of SS IgG alone on the $\left[\mathrm{Ca}^{2+}\right]_{\mathrm{i}}$. Stimulation with $10^{-5} \mathrm{M} \mathrm{CCh}$ (dark bars) increased the $\left[\mathrm{Ca}^{2+}\right]_{\mathrm{i}}$, whereas SS IgG (a white bar), which was applied in between CCh stimulation, does not evoke any $\left[\mathrm{Ca}^{2+}\right]_{\mathrm{i}}$ transient. (b) Effects of SS IgG on the ATP-induced $\left[\mathrm{Ca}^{2+}\right]_{\mathrm{i}}$ transient (AICT). The HSG cells were incubated with the IgGs for $24 \mathrm{~h}$ prior to $10^{-5} \mathrm{M}$ ATP stimulation for $3 \mathrm{~min}$ (indicated by the dark bars in the lower panel). The upper and lower panel is a representative AICT of the control and SS IgG incubation group, respectively.

though the HSG cells consistently responded to $10^{-5} \mathrm{M}$ CCh (indicated by a dark bar) by increasing the $\left[\mathrm{Ca}^{2+}\right]_{\mathrm{i}}$. The same result was obtained in the other five cells. The acute application of SS IgG during the CICT did not cause any changes in the
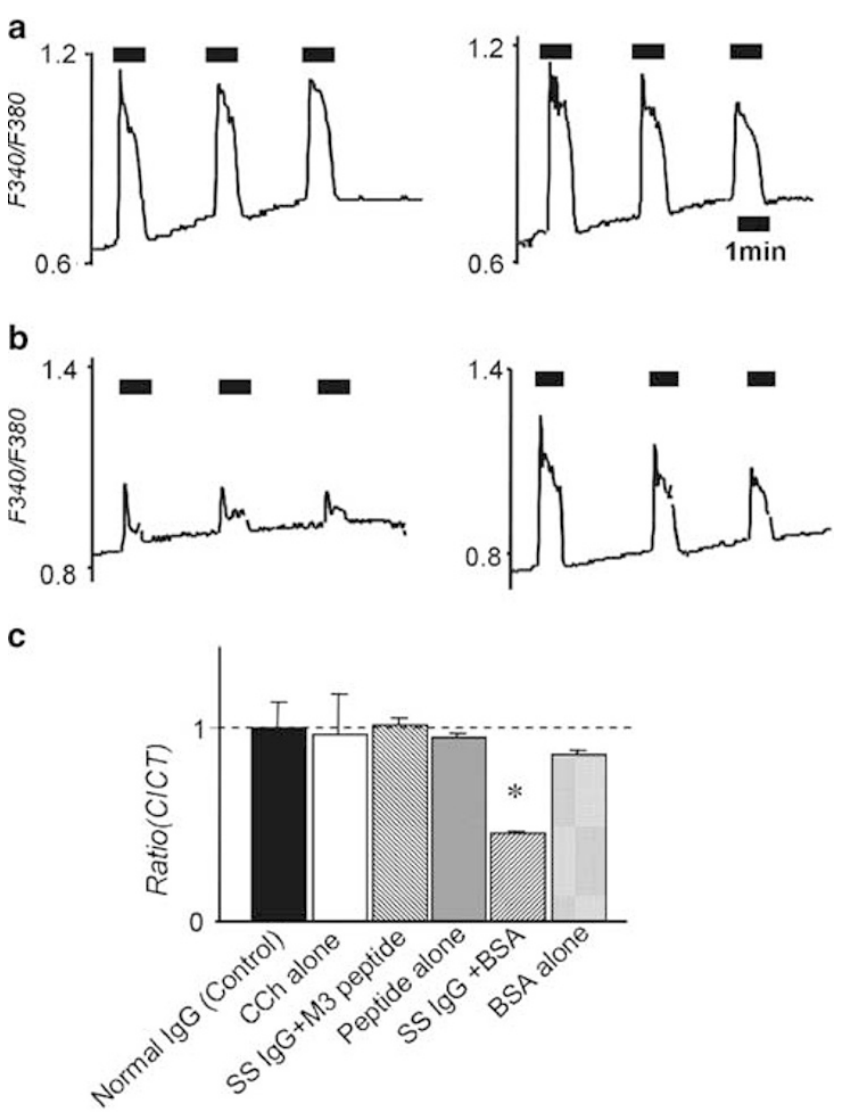

Figure 4 (a) M3R peptides-induced recovery of CICT upon SS IgG incubation for $24 \mathrm{~h}$ (left panel). Cells were incubated with SS IgG that had been preincubated with M3R peptides for $24 \mathrm{~h}$. As control, CICTs were measured in the presence of M3R peptides alone (right panel). (b) An effect of nonspecific peptides on CICT under the same experimental condition. Cells were incubated with SS IgG that had been preincubated with nonspecific peptides derived from BSA. Nonspecific peptides did not recover the decreased CICT (left panel). The nonspecific peptides alone did not affect the control CICT (right panel) either. (c) The data in (a) and (b) are summarized and represented in a graph. *The differences were statistically significant in unpaired $t$-test $(P<0.05)$. Each experimental value is normalized to the value of normal IgG-treated sample.

$\left[\mathrm{Ca}^{2+}\right]_{\mathrm{i}}$ either $(n=4$, data not shown). We next examined whether the inhibitory effect of SS IgG on the $\left[\mathrm{Ca}^{2+}\right]_{i}$ is receptor-specific. Figure $3 \mathrm{~b}$ shows a typical ATP $\left(10^{-5} \mathrm{M}\right)$-induced $\left[\mathrm{Ca}^{2+}\right]_{\mathrm{i}}$ transient (AICT) after incubating the HSG cells with the control (the upper panel) or SS IgG (the lower panel) for $24 \mathrm{~h}$. Throughout the experiments, the HSG cells consistently responded to ATP by increasing the $\left[\mathrm{Ca}^{2+}\right]_{\mathrm{i}}$. In contrast to the decreased CICT (Figure 2b), the magnitudes of the AICT in the SS IgGtreated group under the same experimental condition were not significantly different from those of control group (Figure $3 \mathrm{~b}$ ). The magnitude of the AICT $\left(\Delta\left[\mathrm{Ca}^{2+}\right]_{\mathrm{i}}\right)$ was $1.73 \pm 0.47 \quad(n=4)$ and $2.08 \pm 0.88(n=9)$ in the $24 \mathrm{~h}$ control and SS IgG groups, respectively $(P>0.1)$.

Although above data suggest that SS IgG may act on $\mathrm{M} 3$ receptors, we cannot exclude the possibility 
that the effects of SS IgG on HSG cells are due to its binding to cell surface molecule other than M3R. To rule out this possibility, we competed the effects of SS IgG on CICT using M3R peptides. The left panel of Figure 4a shows that the inhibitory effect of SS IgG on the CICT in HSG cells is completely abrogated by the pre-incubation of SS IgG with the M3R peptides for $24 \mathrm{~h}$. This result indicates that the inhibitory effect of SS IgG on the CICT is mediated by the anti-M3R antibody in the sera. Incubation of HSG cells with M3R peptides alone does not have any effect on the CICT (right panel in Figure 4a). We also tested if the effects of M3R peptides are sequence-specific by using nonspecific peptides as control. The nonspecific peptides were derived from BSA by trypsin-digestion. The left panel of Figure $4 \mathrm{~b}$ shows that nonspecific peptides did not recover the decreased CICT under the same experimental condition. The nonspecific peptides alone did not affect on the CICT either (right panel in Figure 4b). These results are summarized and presented in a graph (Figure 4c). The value of CICT stimulated by CCh alone (without IgG incubation) was not much different to that of the contol value $(96 \pm 2 \%$, $n=16, P>0.1)$. When the SS IgG were preincubated with M3R peptides, but not in the nonspecific peptides, the decrease in the CICT was completely abolished. The addition of M3R peptides in the absence of SS IgG have little effect on the control CICT ( $95 \pm 2 \%, n=16, P>0.1)$, and neither with the addition of nonspecific peptides $(85 \pm 2 \%, n=23$, $P>0.1)$.

\section{Effect of SS IgG on the Pilocarpine-Induced AQP-5 Expression}

AQP-5 is expressed in the apical membrane in serous acinar cells, and plays an important role in primary saliva production. Therefore, the effect of SS IgG on the AQP-5 expression level was investigated. To start this study, we examined the expression of AQP-5 in rat parotid acinar cells by immunohistochemistry. Figure $5 \mathrm{~b}$ shows that AQP5 are expressed exclusively on the apical memebrane of the rat parotid acinar cells, which are shown as dark brown lines (indicated by arrows). Figure 5a is a control tissue that was treated with the secondary antibody alone. Then, the effect of SS IgG on AQP-5 trafficking was examined. For this purpose, we purified APM of rat parotid acinar cells and used for Western blot assay. As shown in Figure $6 a$, without any stimulation, a low basal level of AQP-5 is expressed on the APM of rat parotid acinar cells (lane C), which was increased significantly by the treatment of pilocarpine $\left(10^{-5} \mathrm{M}\right.$ ) for 3 min (lane $\mathrm{P})$. We then examined whether incubating the cells with SS IgG $(0.5 \mathrm{mg} / \mathrm{ml})$ for $1 \mathrm{~h}(\mathrm{~S} 1), 6 \mathrm{~h}(\mathrm{~S} 6)$ and $12 \mathrm{~h}$ (S12) could affect the pilocarpine-induced AQP-5 expression in APM. As controls, cells were incubated with normal IgG for $1 \mathrm{~h}$ (C1), $6 \mathrm{~h} \mathrm{(C6)} \mathrm{and} 12 \mathrm{~h}$
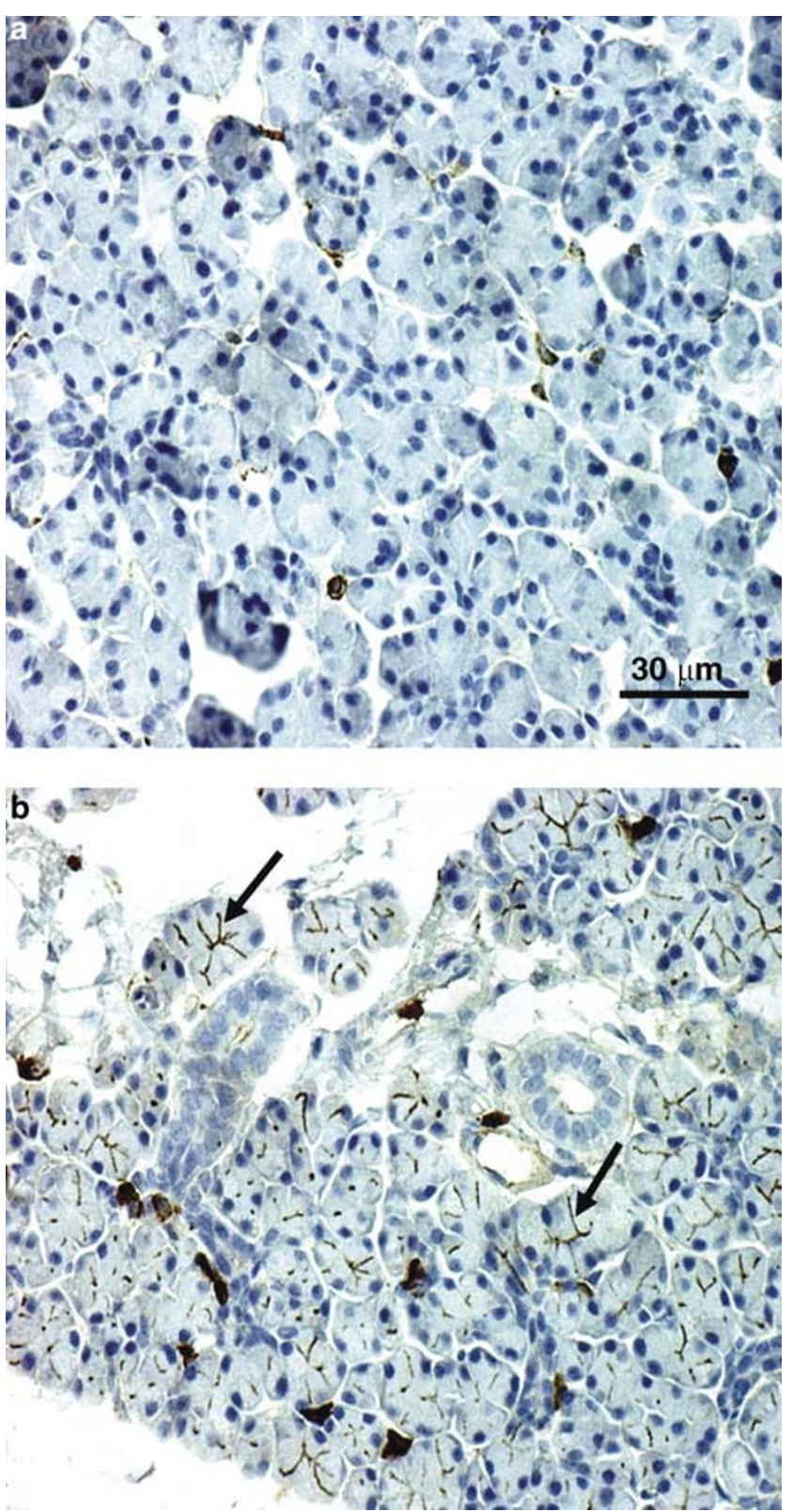

Figure 5 (a) A control tissue that was treated with the secondary antibody alone in the rat parotid acinar cells. (b) AQP-5 expression in the rat parotid acinar cells. Cells were immunostained using a rabbit anti-rat AQP-5 antibody (diluted 1:200 followed by the secondary antibody (diluted 1:200). Many of the dark brown lines (indicated by arrow) exclusively located on the apical membrane in acinar cells are regarded as AQP-5.

(C12). Interestingly, the expression levels of AQP-5 in the SS IgG-treated cells decreased compared to the levels in the normal IgG-treated cells. The inhibitory effect of the SS IgG on the pilocarpineinduced AQP-5 appears to be proportional to the incubation periods. The expression of pilocarpineinduced AQP-5 in S1 and S6 is slightly lower than C1 and C6, respectively. However, a significant decrease in the AQP-5 level was observed upon SS IgG incubation for $12 \mathrm{~h}$ (compare lanes S12 and 
a

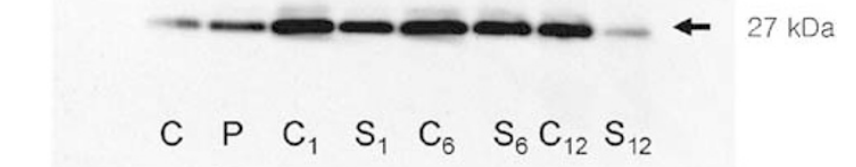

b

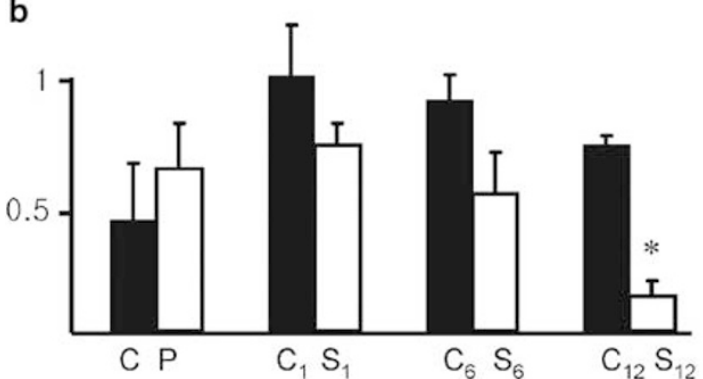

Figure 6 (a) Effects of SS IgG on the pilocarpine-induced increase in the AQP-5 level in the APM (5 $\mu \mathrm{g})$. The two left lanes show the amount of AQP-5 before (C: control) and after pilocarpine stimulation (P). All of the lanes marked with ' $S$ ' indicate the amount of pilocarpine-induced AQP-5 after incubating the cells with SS IgG for $1 \mathrm{~h}$ (S1), $6 \mathrm{~h}$ (S6) and $12 \mathrm{~h}$ (S12). Both primary and secondary antibodies were used at dilutions of 1:2000. The lanes marked with ' $C$ ' indicate the control groups in which normal healthy IgG was added to the incubation medium for the same periods. (b) The amount of AQP-5 in (a) was quantified using densitometry and represented in a graph. Each value was normalized to the densitometric value of AQP-5 in lane C1. A significant decrease in the AQP-5 level $(n=4, P<0.05)$ was observed after $12 \mathrm{~h}$ in the SS IgG incubation group (indicated by *).

C12). The expression levels of AQP-5 in each sample are quantified using densitometer, and the data are presented in Figure $6 \mathrm{~b}$. The brightest band of the third lane (C1) was regarded as 1. A significant decrease in the AQP-5 level $(P<0.05)$ was observed in the $12 \mathrm{~h}$ SS IgG incubation group.

\section{Discussion}

It has been known that the impaired secretory function in SS patients is not due to the destruction of neural innervation or the absence of receptors in the residual glandular tissue. Rather, it is more likely that cytokines or autoantibodies released by glandular cells in SS patients decrease responses of the residual glandular cells to the neurotransmitters. Although it was reported that human sera of SS patients stimulates M3R of rat parotid cells ${ }^{14}$ and IgG purified from SS patients binds to M3R of lacrimal gland, ${ }^{15,16}$ there are no direct evidence of the interaction of SS IgG with human M3R. In our study, we found that the function of M3R in human salivary cell lines is downregulated when the cells are pre-exposed to the SS IgG, which could partly explain the associated features of the salivary dysfunction in SS patients.

The stimulation of HSG cells with CCh increases the $\left[\mathrm{Ca}^{2+}\right]_{\mathrm{i}}$, which appears to be released from an intracellular $\mathrm{Ca}^{2+}$ store. ${ }^{22}$ In our study, preincubation of the cells in SS IgG for 12 or $24 \mathrm{~h}$ decreased the CICT. Furthermore, the addition of M3R peptides completely recovered the SS IgG-mediated decrease in CICT. These data indicate that the inhibitory effect of SS IgG on CICT is mediated by autoantibodies in the SS IgG that bind to the M3R on the HSG cells. The reduction in the response to muscarinic agonist may be partly due to a general reduction of signal transduction components as a consequence of the autoantibodies directed against the cell surface receptors. The serum IgG from SS patients is reported to compete the binding of muscarinic receptor agonist to salivary gland membranes. ${ }^{23}$ Likewise, persistent loss of sensitivity to Ach was reported in salivary acinar cells that obtained from SS patients. ${ }^{24}$ Interestingly, SS IgG induced a similar degree of inhibition in the CChevoked bladder contraction by approximately $50 \%,{ }^{25}$ suggesting that CICT is also reduced in this tissue, because $\left[\mathrm{Ca}^{2+}\right]_{\mathrm{i}}$ also plays a putative role in smooth muscle contractions.

It is noted that the effect of SS IgG on M3R is dependent on the incubation periods. The inhibitory effect is pronounced only after $12 \mathrm{~h}$. However, upon an acute application of SS IgG, the magnitude of subsequent CICT was rather increased (see Figure 3a), suggesting a stimulatory effect of SS IgG on M3R. ${ }^{15}$ Although it is speculative, we can conjecture that the autoantibodies act initially as an agonist, but then lead to the downregulation of the receptor after the long-term exposure. The role of cytokines in the increase in intracellular calcium level in acinar cells appears to be still controversial. In primary mouse submandibular acinar cells, cytokines does not play any role in the increase of intracellular calcium level. ${ }^{26}$ However, the study of $\mathrm{Wu}$ et $a 1^{27}$ revealed that persistent exposure of IFNgamma/TNFalpha induces the depletion of internal calcium stores in HSG cells. These data indicate that different effects or results can be expected when different cell types/lines or different experimental settings are used.

The localization of AQP-5 in the APM and its increase by pilocarpine, a well-known cholinergic agonist that stimulates the salivary secretion, ${ }^{28-30}$ has been documented by previous reports. ${ }^{13}$ When the parotid acinar cells were incubated with SS IgG, the amount of AQP-5 in the APM was significantly lower than that in the normal IgG-stimulated cells, suggesting that the incubation in SS IgG may alter the normal AQP-5 trafficking. The decrease in AQP5 in the APM can contribute to the deficiency of fluid secretion, which is the key feature of SS. ${ }^{10}$ Decreased water permeability in the parotid acinar 
cells and salivary secretion was also detected in the transgenic mice lacking AQP-5. ${ }^{31,32}$ We observed a slight increase in the AQP-5 expression in the APM of normal IgG-incubated cells. Although it is not clear how normal IgG increases the AQP-5 level at the moment, it does not appear to change any of the conclusions reached, since we always compared the differences between the two sets of experiments, the control (incubated with normal IgG) and the SS IgG group in the same periods. Prolonged incubation periods may cause a subtle change in filling status of $\left[\mathrm{Ca}^{2+}\right]_{\mathrm{i}}$ in intracellular Ca store and possibly accelerate trafficking of AQP5 to APM by pilocarpine stimulation. The elevation of the cytosolic $\mathrm{Ca}^{2+}$ levels induced by muscarinic agonist play a critical role in the trafficking of AQP-5 between the ICM and APM in the rat parotid glands. ${ }^{33}$ As expected, neither the application of SS IgG alone nor SS IgG application during the CICT caused any changes in the $\left[\mathrm{Ca}^{2+}\right]_{i}$, suggesting that a certain amount of exposure time for the SS autoantibodies is needed to interact with the surface membrane muscarinic receptor. In conclusion, our data suggest that autoantibodies against the M3 muscarinic receptors in the sera of SS patients may induce functional impairment of the secretory processes as well as the salivary dysfunction observed in SS.

\section{Acknowledgements}

We thank Dr Toshiko Atzumi in Meikai University in Japan for generous gift of HSG cell lines. This work was supported by a grant of the Korea Health 21 R\&D project, Ministry of Health \& Welfare, Republic of Korea (Grant No. 01-PJ5-PG1-01CH120002).

\section{References}

1 Fox RI, Michelson P, Casiano CA, et al. Sjögren’s syndrome. Clin Dermatol 2000;18:589-600.

2 Gannot G, Lancaster HE, Fox PC. Clinical course of primary Sjögren's syndrome: salivary, oral, and serologic aspects. J Rheumatol 2000;27:1905-1909.

3 Nauntofte B. Regulation of electrolyte and fluid secretion in salivary acinar cells. Am J Physiol 1992; 263:G823-G837.

4 Petersen OH. Stimulus-secretion coupling: cytoplasmic calcium signals and the control of ion channels in exocrine acinar cells. J Physiol 1992;448:1-51.

5 Baum BJ. Principles of saliva secretion. Ann NY Acad Sci 1993;694:17-23.

6 Turner RJ. Mechanisms of fluid secretion by salivary glands. Ann NY Acad Sci 1993;694:24-35.

7 Ambudkar IS, Hiramatsu Y, Lockwich T, et al. Activation and regulation of calcium entry in rat parotid gland acinar cells. Crit Rev Oral Biol Med 1993;4: 421-425.

8 Ambudkar IS. Regulation of calcium in salivary gland secretion. Crit Rev Oral Biol Med 2000;11:4-25.
9 Park K, Case RM, Brown PD. Identification and regulation of $\mathrm{K}^{+}$and $\mathrm{Cl}^{-}$channels in human parotid acinar cells. Arch Oral Biol 2001;46:801-810.

10 Tsubota K, Hirai S, King LS, et al. Defective cellular trafficking of lacrimal gland aquaporin-5 in Sjögren's syndrome. Lancet 2001;357:688-689.

11 Steinfeld S, Cogan E, King LS, et al. Abnormal distribution of aquaporin-5 water channel protein in salivary glands from Sjögren's syndrome patients. Lab Invest 2001;81:143-148.

12 Steinfeld SD, Delporte C. Distribution of salivary aquaporin-5 in Sjögren's syndrome. Lancet 2002;359: 1777-1778.

13 Ishikawa Y, Skowronski MT, Ishida H. Persistent increase in the amount of aquaporin-5 in the apical plasma membrane of rat parotid acinar cells induced by a muscarinic agonist SNI-2011. FEBS Lett 2000; 477:253-257.

14 Bacman S, Sterin-Borda L, Camusso JJ, et al. Circulating antibodies against rat parotid gland M3 muscarinic receptors in primary Sjögren's syndrome. Clin Exp Immunol 1996;104:454-459.

15 Bacman S, Perez Leiros C, Sterin-Borda L, et al. Autoantibodies against lacrimal gland M3 muscarinic acetylcholine receptors in patients. Invest Ophthalmol Vis Sci 1998;39:151-156.

16 Bacman S, Berra A, Sterin-Borda L, et al. Muscarinic acetylcholine receptor antibodies as a new marker of dry eye Sjogren's syndrome. Invest Ophthalmol Vis Sci 2001;42:321-327.

17 Vitali C, Bombardieri S, Jonsson R, et al. Classification criteria for Sjögren's syndrome: a revised version of the European criteria proposed by the American-European Consensus Group. Ann Rheum Dis 2002;61:554-558.

18 Horejsi J, Smetana R. The isolation of gamma globulin from blood-serum by rivanol. Acta Med Scand 1956;155:65-70.

19 Tusnady GE, Simon I. Principles governing amino acid composition of integral membrane proteins: application to topology prediction. J Mol Biol 1998;283: 489-506.

20 Tusnady GE, Simon I. The HMMTOP transmembrane topology prediction server. Bioinformatics 2001;17: 849-850.

21 Liu X, Liao D, Ambudkar IS. Distinct mechanisms of $\left[\mathrm{Ca}^{2+}\right]_{\mathrm{i}}$ oscillations in HSY and HSG cells: role of $\mathrm{Ca}^{2+}$ influx and internal $\mathrm{Ca}^{2+}$ store recycling. J Membr Biol 2001;181:185-193.

22 Liu X, Singh BB, Ambudkar IS. ATP-dependent activation of $\mathrm{K}(\mathrm{Ca})$ and ROMK-type K (ATP) channels in human submandibular gland ductal cells. J Biol Chem 1999;274:25121-25129.

23 Robinson CP, Brayer J, Yamachika S, et al. Transfer of human serum IgG to nonobese diabetic Igmu null mice reveals a role for autoantibodies in the loss of secretory function of exocrine tissues in Sjögren's syndrome. Proc Natl Acad Sci USA 1998;95: 7538-7543.

24 Dawson LJ, Field EA, Harmer AR, et al. Acetylcholineevoked calcium mobilization and ion channel activation in human labial gland acinar cells from patients with primary Sjögren's syndrome. Clin Exp Immunol 2001;124:480-485.

25 Waterman SA, Gordon TP, Rischmueller M. Inhibitory effects of muscarinic receptor autoantibodies on parasympathetic neurotransmission in Sjögren's syndrome. Arthritis Rheum 2000;43:1647-1654. 
26 Dawson LJ, Christmas SE, Smith PM. An investigation of interactions between the immune system and stimulus-secretion coupling in mouse submandibular acinar cells. A possible mechanism to account for reduced salivary flow rates associated with the onset of Sjögren's syndrome. Rheumatology (Oxford) 2000; 39:1226-1233.

$27 \mathrm{Wu}$ AJ, Chen ZJ, Baum BJ, et al. Interferon-gamma induces persistent depletion of internal $\mathrm{Ca}^{2+}$ stores in a human salivary gland cell line. Am J Physiol 1996; 270:C514-C521.

28 Wiseman LR, Faulds D. Oral pilocarpine: a review of its pharmacological properties and clinical potential in xerostomia. Drugs 1995;49:143-155.

29 Taylor SE, al-Hashimi I. Pilocarpine, an old drug; a new formulation. Tex Dent J 1996;113:9-13.
30 Nusair S, Rubinow A. The use of oral pilocarpine in xerostomia and Sjögren's syndrome. Semin Arthritis Rheum 1999;28:360-367.

31 Ma T, Song Y, Gillespie A, et al. Defective secretion of saliva in transgenic mice lacking aquaporin-5 water channels. J Biol Chem 1999;274:20071-20074.

32 Krane CM, Melvin JE, Nguyen HV, et al. Salivary acinar cells from aquaporin 5-deficient mice have decreased membrane water permeability and altered cell volume regulation. J Biol Chem 2001;276:23413-23420.

33 Ishikawa Y, Eguchi T, Skowronski MT, et al. Acetylcholine acts on M3 muscarinic receptors and induces the translocation of aquaporin5 water channel via cytosolic $\mathrm{Ca}^{2+}$ elevation in rat parotid glands. Biochem Biophys Res Commun 1998;245: 835-840. 